\title{
Participatory of local operators in ecotourism services delivery: the nature-based tourism development in Pahang National Park, Malaysia
}

\begin{abstract}
This article offers a look at the participation of local operators in delivery of ecotourism services, concentrating on the development of nature-based tourism at Pahang National Park and Taman Negara National Park in Malaysia. According to the author, the development of nature-based tourism depends on the managing agency and conditions by various endogenous and exogenous factors of stakeholders, including local communities. In the case of Malaysia, Taman Negara is administered by the Department of Wildlife and National Parks and consists of three separately managed state parks.
\end{abstract}

Keyword: ecotourism, national park, tourism development, tourism management 